\title{
Ultrastructure and Transovarial Transmission of Endosymbiotic Microorganisms in Conomelus anceps and Metcalfa pruinosa (Insecta, Hemiptera, Fulgoromorpha)*
}

\author{
Anna MichALIK, Władysława JANKOWSKA and Teresa SZKLARZEWICZ
}

Accepted April 20, 2009

\begin{abstract}
MiCHALIK A., JANKOWSKA W., SZKLARZEWICZ T. 2009. Ultrastructure and transovarial transmission of endosymbiotic microorganisms in Conomelus anceps and Metcalfa pruinosa (Insecta, Hemiptera, Fulgoromorpha). Folia biol. (Kraków) 57: 131-137.

Endosymbiotic microorganisms commonly occur in fulgoromorphans, as in other plant sap-sucking hemipterans. Large syncytial organs termed mycetomes are present in the body cavities of Conomelus anceps (Delphacidae) and Metcalfa pruinosa (Flatidae), in the close vicinity of the ovaries. The mycetomes are surrounded by a one-layered epithelium. The mycetome cytoplasm is filled with yeast-like symbiotic microorganisms (YLSs). The YLSs are transovarially transmitted to the next generation. The endosymbionts are released from the mycetomes and migrate towards the ovarioles containing vitellogenic oocytes. The YLSs pass through the cells of the ovariole stalk (pedicel) and enter the perivitelline space. Then, a deep depression is formed at the posterior pole of the oocyte. The YLSs accumulate in the oocyte depression and form a characteristic "symbiont ball". The mycetome cytoplasm of Metcalfa pruinosa as well as epithelial cells surrounding the mycetome contain small, rod-shaped bacteria.

Key words: Endosymbiotic microorganisms, transovarial transmission, ovariole, Fulgoromorpha, planthoppers.

Anna MICHALIK, Wtadystawa JANKOWSKA, Teresa SZKLARZEWICZ, Department of Systematic Zoology and Zoogeography, Institute of Zoology, Jagiellonian University, R. Ingardena 6 , 30-060 Kraków, Poland.

E-mail:szkla@iz.uj.edu.pl
\end{abstract}

Fulgoromorphans, like other plant sap-sucking hemipterans, harbor obligate, intracellular symbiotic microorganisms (see BUCHNER 1965; HOUK \& GRIFFITHS 1980; BAUMANN 2005, 2006, for further details). Endosymbiotic microorganisms are housed in large cells termed mycetocytes (=bacteriocytes). Mycetocytes are usually integrated into discrete organs termed mycetomes (=bacteriomes) that in some hemipterans may be surrounded by a one-layered epithelium. BUCHNER (1965) on the basis of comparative studies of all hemipteran groups distinguished two categories of endosymbiotic microorganisms: primary endosymbionts (currently called P-symbionts) and accessory endosymbionts (currently called facultative, secondary or S-symbionts). Primary endosymbionts are always present in all the specimens, whereas secondary endosymbionts occur in some populations only. More recent studies have shown that the occurrence of primary endosymbionts in the insect body is related to a restricted diet, deficient in some essential nutrients (see BAUMANN 2005, 2006, for full review). Since hemipterans feed on phloem sap devoid of amino acids, their primary endosymbionts are responsible for amino acid synthesis and delivery to the host insect (e.g. SASAKI \& ISHIKAWA 1995; WILKINSON \& ISHIKAWA 2001). Thus, the occurrence of primary endosymbionts is necessary for the survival and reproduction of the host insects. In contrast to primary endosymbionts, the role of the secondary endosymbionts for their host insects remains unclear. Recent studies revealed that aphids harboring Ssymbionts may better survive heat stress (MONTLLOR et al. 2002) as well as attacks by parasitic hymenopterans (OLIVER et al. 2003) and fungal pathogens (SCARBOROUGH et al. 2005) than sterile specimens.

The symbiotic associations between primary endosymbionts and insects are the results of ancient in-

\footnotetext{
* Supported by Research Grant DS/IZ/ZS/2008.
} 
fections with free living bacteria (BAUMANN 2006), whereas associations between secondary endosymbionts and insects are much younger and are due to multiple, independent infections (THAO et al. 2000).

Most hemipterans have prokaryotic endosymbionts, however, eukaryotic microorganisms historically termed "yeast-like symbionts" (YLSs) occur in some aphids, scale insects, leafhoppers and fulgoromorphans (see BUCHNER 1965; ISHIKAWA 2003, for further details).

Both bacterial and yeast-like endosymbionts are maternally inherited by transovarial transmission. Studies on transovarial transmission of bacterial endosymbionts have shown that variable modes of ovary infection by bacteria exist in insects (ŻELAZOWSKA \& BILIŃSKI 1999; SZKLARZEWICZ \& MOSKAL 2001; SZKLARZEWICZ et al. 2006). The endosymbiotic microorganisms may invade young germ cells (=cystocytes) or oocytes in the older stage of development (i.e. vitellogenic or choriogenic). The ovaries may be invaded by bacteria or by intact mycetocytes. The endosymbionts may migrate through the neighboring follicular cells (i.e. cells surrounding oocytes) or may enter the cytoplasm of follicular cells. In contrast to bacterial endosymbionts, the transovarial transmission of YLSs is poorly known, and there are only three published observations on this process (NODA 1977; CHENG \& HOU 2001; SACCHI et al. 2008), two of which consider members of the family Delphacidae.

The present study was undertaken to provide information about the mode of transmission of YLSs in Metcalfa pruinosa, a member of the Flatidae family, and in another member of the family Delphacidae, Conomelus anceps.

\section{Material and Methods}

Adult specimens of Conomelus anceps (Germar, 1821) were collected in July near Nowy Targ (southern Poland). Adult specimens of Metcalfa pruinosa (Say, 1830) were collected in July in Grabels (southern France). The abdomens and dissected ovaries of individuals of each species were fixed in $2.5 \%$ glautaraldehyde in 0.1 phosphate buffer ( $\mathrm{pH}$ 7.4) for three months. The material was then rinsed in $0.1 \mathrm{M}$ phosphate buffer $(\mathrm{pH} 7.4)$ with addition of $5.8 \%$ sucrose, postfixed in $1 \%$ osmium tetroxidae, dehydrated in a series of alcohol and acetone and embedded in epoxy resin Epox 812 (Fullam Inc., Latham, N.Y., USA). Semithin sections were stained with $1 \%$ methylene blue in $1 \%$ borax and photographed in a Jenalumar (Zeiss Jena) microscope. Ultrathin sections were stained with lead citrate and uranyl acetate and examined using a JEM 100 SX electron microscope at $80 \mathrm{kV}$.

\section{Results}

Gross morphology of the ovaries

The paired ovaries of Metcalfa pruinosa and Conomelus anceps consist of several ovarioles of telotrophic type (Fig. 1). The individual ovariole is subdivided into a terminal filament, tropharium (trophic chamber), vitellarium and ovariolar stalk (pedicel) that joins the ovariole to the lateral oviduct (Fig. 1). The tropharium is composed of syncytial lobes containing 3-5 trophocyte nuclei (Fig. 1). Early previtellogenic oocytes (termed arrested oocytes) and prefollicular cells are present at the base of the tropharium (Fig. 1). The vitellarium in mature females comprises 4-5 linearly arranged oocytes that are surrounded by a one-layered follicular epithelium (Fig. 1). The vitellarial oocytes develop through

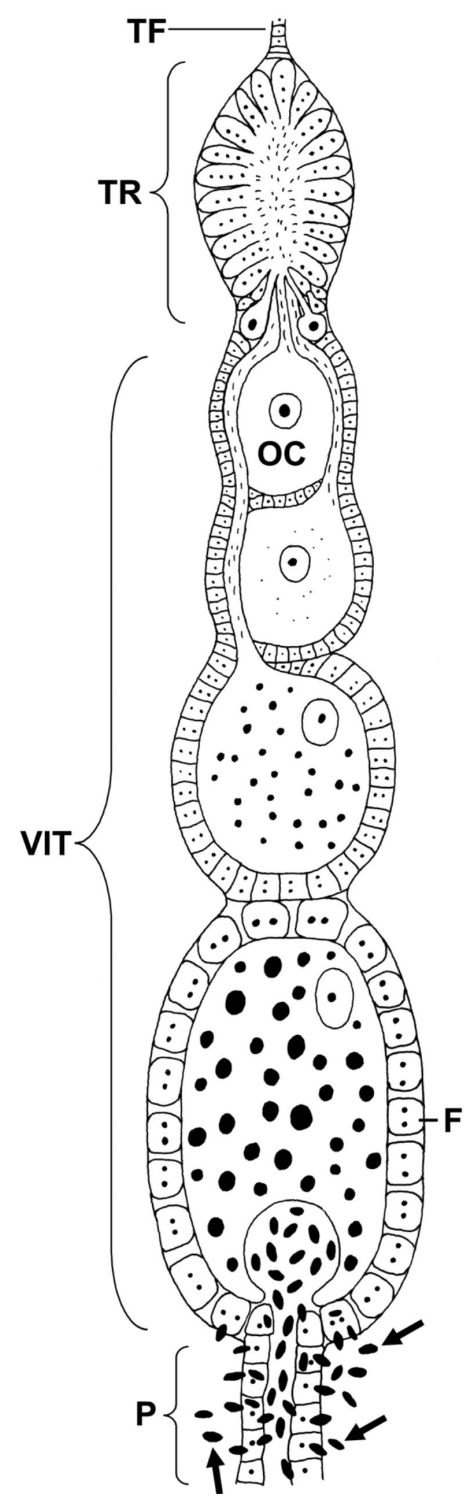

Fig. 1. Schematic representation of the ovariole of a planthopper. Arrows - YLSs; F - follicular epithelium; OC - oocyte; TF - terminal filament; TR - tropharium; VIT vitellarium; $\mathrm{P}$ - pedicel. 

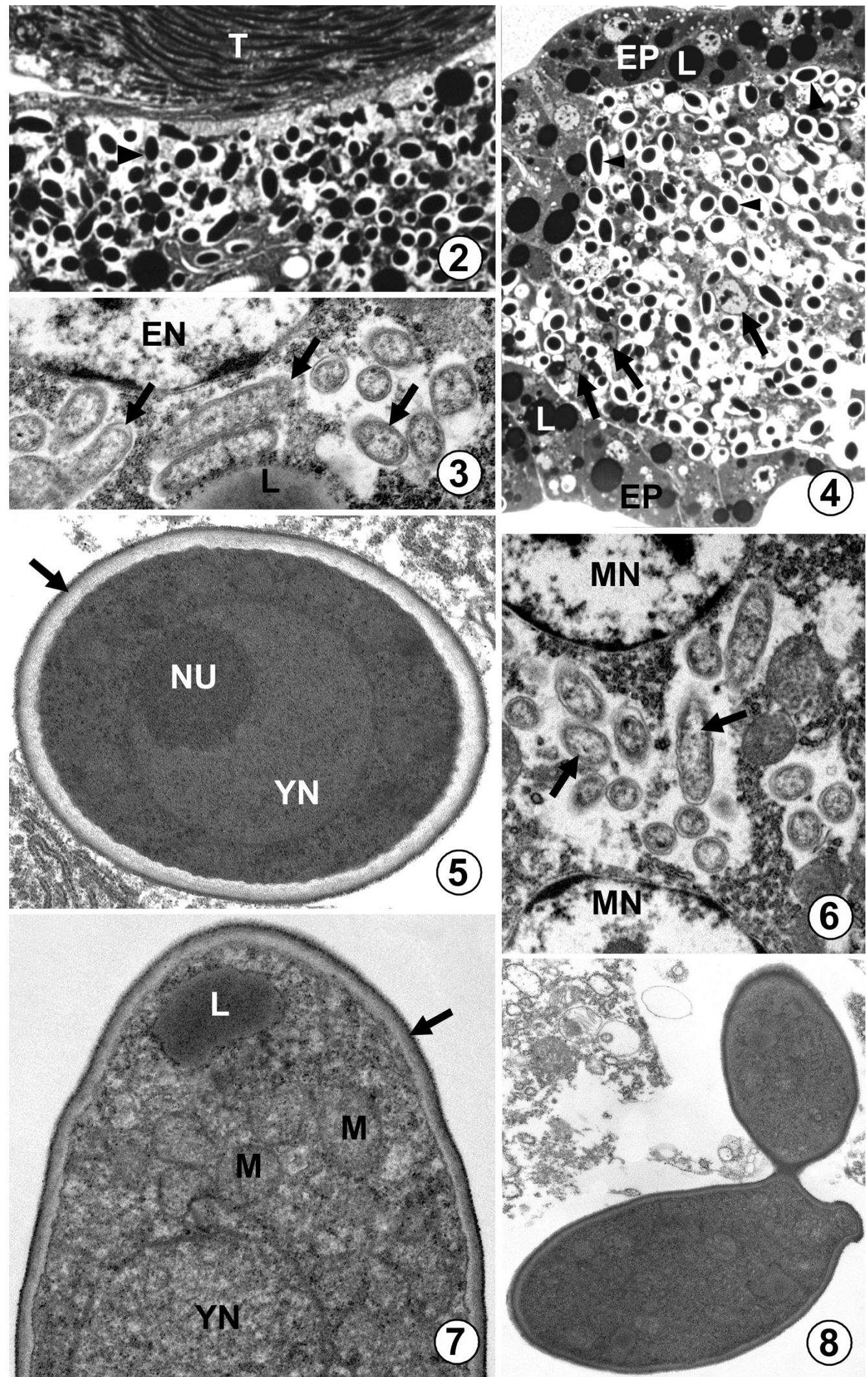

Figs 2-8. Fig. 2. M. pruinosa. The mycetome filled with YLSs (arrowhead) in the body of the male. T - testis. Methylene blue, $\times$ 570. Fig. 3. M. pruinosa. Fragment of the epithelial cell surrounding the mycetome. Arrows - rod-shaped bacteria; EN nucleus of the epithelial cell; L - lipid droplet. TEM, $\times 18$ 100. Fig. 4. C. anceps. The mycetome filled with YLSs (arrowheads) in the body of the female. Arrows - mycetome nuclei embedded in the common cytoplasm: EP - epithelial cells surrounding the mycetome; $\mathrm{L}-$ lipid droplets. Methylene blue, $\times 530$. Fig. 5. M. pruinosa. Cross section through the cell of the YLS. Arrow - cell wall composed of two distinct layers; YN - nucleus; NU - nucleolus. TEM, $\times 16$ 500. Fig. 6. M. pruinosa. Fragment of the mycetome cytoplasm. Arrows - rod-shaped bacteria; MN - mycetome nuclei embedded in the common cytoplasm. TEM $\times 17$ 500. Fig. 7. M. pruinosa. Fragment of the cell of the YLS. Arrow - cell wall: L - lipid droplet: M mitochondria; YN - nucleus. TEM, $\times 15$ 100. Fig. 8. C. anceps. The YLS reproducing by budding. TEM, $\times 9300$. 
three stages: previtellogenesis (i.e. synthesis and accumulation of RNA's), vitellogenesis (i.e. synthesis and accumulation of reserve substances) and choriogenesis (i.e. synthesis and secretion of precursors of eggshells and their deposition on the oocyte surface) (for a detailed description of ovaries of planthoppers see SZKLARZEWICZ et al. 2007).

Ultrastructure, distribution and transovarial transmission of yeast-like endosymbiotic microorganisms

Both in males and females of $C$. anceps and $M$. pruinosa, the spaces between internal organs are filled with large structures termed mycetomes (Figs 2,4). The mycetomes have a syncytial character, i.e. they have numerous nuclei embedded in a common cytoplasm (Figs 4, 6). The mycetomes are surrounded by a one-layered epithelium (Fig. 4). In young specimens epithelial cells are small, izodiametric and closely adhere to each other (not shown), while in the older specimens they become irregular and voluminous with large lipid droplets in the cytoplasm (Fig. 4). Numerous rod-shaped bacteria occur in epithelial cells (Fig. 3) as well as in mycetome cytoplasm (Fig. 6) of all examined specimens of M. pruinosa. The bacteria measure $1.2-1.6 \mu \mathrm{m}$ in length and $0.3-0.5 \mu \mathrm{m}$ in diameter. Both in M. pruinosa and C. anceps, the mycotome cytoplasm contains an enormous number of yeast-like symbionts (YLSs) (Figs 2, 4). The size of YLSs is $8-10 \mu \mathrm{m}$ in length and 3,0-3,5 $\mu \mathrm{m}$ in diameter. They are surrounded by a thick cell wall composed of two distinct layers (Figs 5, 7, 8). The
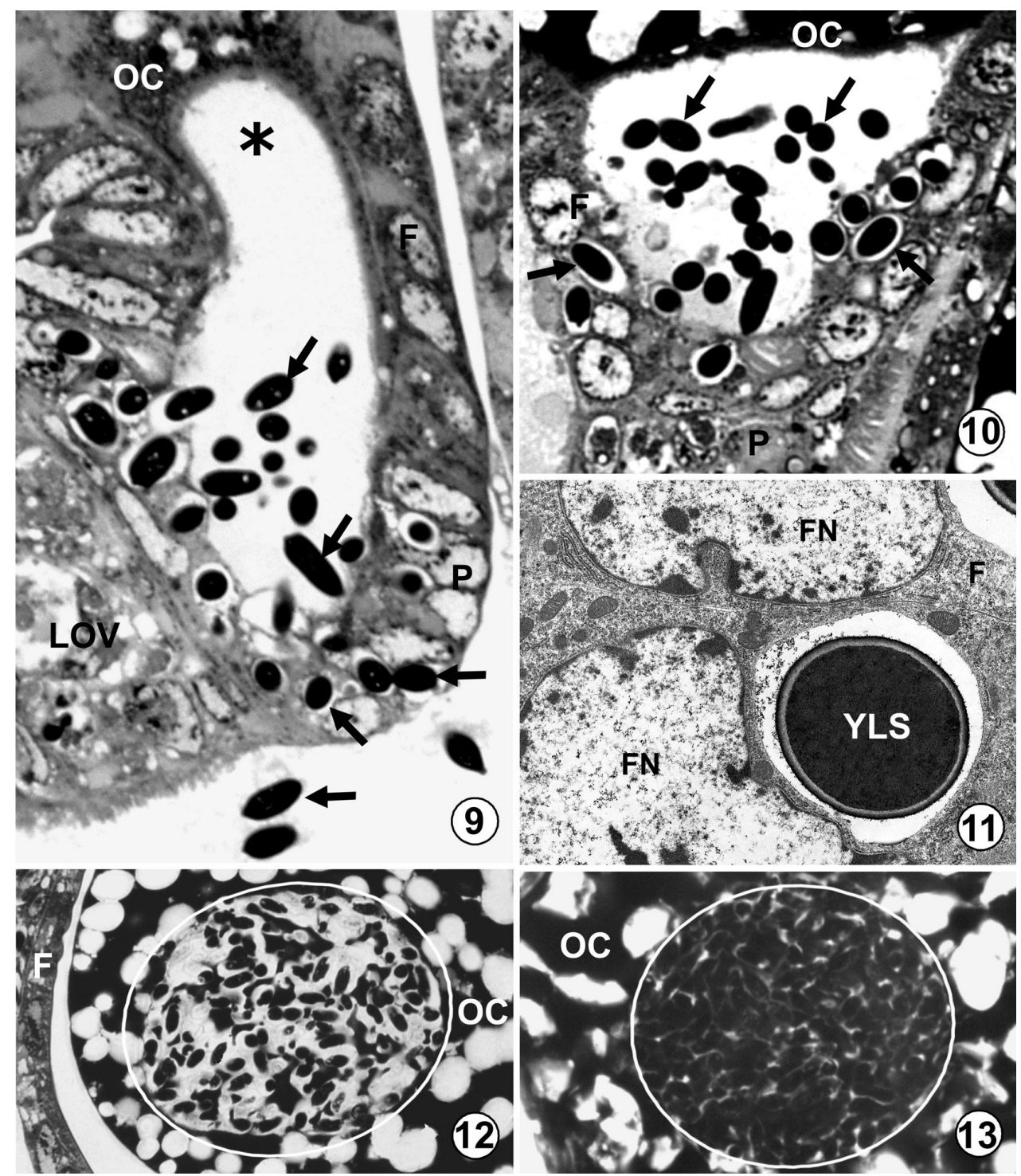

Figs 9-13. Figs 9, 10. Longitudinal section through the posterior end of the ovariole, pedicel $(\mathrm{P})$ and lateral oviduct (LOV) during infection by the YLSs (arrows). Methylene blue, $\times 1$ 000. Fig. 9. C. anceps. Fig. 10. M. pruinosa. Asterisk - deep depression of the oolemma; F - follicular cells; OC - oocyte. Fig. 11. C. anceps. Fragment of the follicular epithelium (F) during migration of YLSs. FN - follicular cell nucleus. TEM, $\times 6500$. Figs 12, 13. C. anceps. Cross section through the posterior pole of the ovariole containing a "symbiont ball" filled with YLSs (encircled). TEM, $\times 500$. Fig. 12. Oocyte during late vitellogenesis stage; Fig. 13. Full-grown oocyte. F - follicular epithelium; OC - oocyte. 
outer layer is electron dense and has a thickness of $30 \mathrm{~nm}$. The inner layer has lower electron density and is $140 \mathrm{~nm}$ thick. In the central part of the yeast cell a large, spherical nucleus with a single nucleolus is present (Fig. 5). The remaining cytoplasm is filled with ribosomes, mitochondria and large lipid droplets (Fig. 7). The YLSs reproduce by budding (Fig. 8). Sexual reproduction of YLSs was not observed. In older females (i.e. containing terminal oocytes in the stage of late vitellogenesis), the YLSs leave the mycetome cytoplasm. They become released into a haemolymph and migrate towards the terminal oocytes (Fig. 9). The endosymbionts pass through the cells of the ovariole stalk (pedicel) (Fig. 9) as well as follicular cells surrounding the posterior pole of the oocyte (Fig. 10, 11). Subsequently, they enter the perivitelline space (Figs 9, 10). At the same time a deep depression is formed at the posterior pole of the oocyte. The YLSs accumulate in the oocyte depression and form a characteristic "symbiont ball" (Fig. 12). At the end of oocyte growth, the "symbiont ball" is tightly packed with YLSs (Fig. 13). Until the end of oocyte growth the YLSs are isolated from the ooplasm by oolemma and do not enter the ooplasm. The endosymbionts gathered in the depression of the oocytes, like those harbored in the mycetome, undergo budding (not shown).

\section{Discussion}

Our observations revealed that both adult males and females of M. pruinosa (Flatidae) as well as C. anceps (Delphacidae) harbor a large number of intracellular YLSs. This observation shows that these endosymbionts are essential for both sexes of examined planthoppers. In recent years, the metabolic significance of YLSs for growth and reproduction of the host insects has been extensively studied using the rice brown planthopper, Nilaparvata lugens (SASAKI et al. 1996; HONGOH \& ISHIKAWA 1997, 2000; WILKINSON \& ISHIKAWA 2001). These studies revealed that planthopper YLSs are involved in nitrogen recycling using uric acid as a nitrogenous resource. Planthoppers, in addition to producing uric acid as a nitrogenous waste product, also synthesize it as a storage product during nitrogen deficiency. Uric acid is stored in mycetomes and converted by uricase, secreted by YLSs, into compounds of nutritional value. It should be noted that CHENG and HOU (2005) demonstrated that YLSs are also engaged in synthesis of yolk precursors in females of the rice brown planthopper, Nilaparvata lugens.

Our studies showed that YLSs in M. pruinosa and $C$. anceps are transmitted from the mother to the progeny by a similar route, i.e. via cytoplasm of cells of the pedicel as well as follicular cells sur- rounding the posterior pole of the oocyte. Since the same situation has been observed in other members of the family Delphacidae, i.e. Laodelphax striatellus (NODA 1977) and Nilaparvata lugens (CHENG \& HOU 2001) as well as in the leafhopper, Scaphoideus titanus (SACCHI et al. 2008), it seems probable that all hemipterans have developed the same mode of transmission of YLSs to the next generation. Thus, the transmission of YLSs in insects is more uniform than the transmission of bacteria (see Introduction). Moreover, molecular studies revealed that YLSs in hemipterans are not only similarly inherited but are also phylogenetically closely related to each other. The analysis of $18 \mathrm{~S}$ ribosomal DNA sequences of YLSs in delphacids (NODA et al. 1995; XET-MULL et al. 2004), aphids (FUKATSU \& ISHIKAWA 1996) and leafhoppers (SACCHI et al. 2008) indicated that they belong to the class Pyrenomycetes in the phylum Ascomytina. The YLSs in the examined rice delphacids are characterized by a high degree of similarity of $18 \mathrm{~S}$ ribosomal DNA sequences (NODA et al. 1995; XETMuLL et al. 2004). This finding strongly suggests that YLSs of delphacids are closely related (i.e. constitute a monophyletic group). This implies, in turn, that the symbiosis of YLSs and delphacids is the result of a single infection of the common ancestor of present delphacids. The YLSs harbored in members of the Flatidae family have so far not been examined by molecular methods, therefore their systematic position remains unknown. Since flatids and delphacids are phylogenetically distant within planthoppers (i.e. do not represent a monopyletic taxon) (BOURGOIN et al. 1997; URBAN \& CRYAN 2007), it is unlikely that their endosymbionts have been acquired through a common ancestor. In this light, it may be assumed that YLSs were horizontally transferred between flatid and delphacid lineages. It is noteworthy that HONGOH and ISHIKAWA (2000), on the basis of an analysis of uricase gene sequences of YLSs in aphids and delphacids, provided evidence of a close relationship between YLSs in these phylogenetically distant groups of insects as a result of the horizontal transfer of microorganisms from the aphid to the planthopper lineage.

Both in M. pruinosa and C. anceps, the migration of YLSs is correlated with ovary development (the YLSs infect vitellogenic oocytes). Thus, this observation strongly supports the hypothesis that the movement of microorganisms is stimulated by an unknown factor released by ovaries (EBERLE \& MC LEAN 1982; ŻELAZOWSKA \& BILIŃSKI 1999; SZKLARZEWICZ \& MOSKAL 2001; SZKLARZEWICZ et al. 2006).

We observed that apart from YLSs, rod-shaped bacteria are present in the body of all specimens of M. pruinosa. In contrast to YLSs, bacteria have never been found in the ovaries of M. pruinosa. 
The absence of these bacteria in the ovaries indicates that they may be horizontally transmitted between specimens. The large number of bacteria both in the mycetome cytoplasm as well as in its epithelium suggests that they may have a significant (positive or negative) influence on the host insect. These microorganisms may represent S-symbionts of $M$. pruinosa, but may also prove to be pathogenic. It should be noted that NODA and SAITO (1979) detected rod-shaped bacteria in mycetomes of the planthopper Laodelphax striatellus (Delphacidae) but did not suggest a possible role for them. It may be also speculated that these bacteria belong to the widespread within arthropods ricketsia-like genus Wolbachia pipientis. The last assumption is supported by PCR detection of Wolbachia in two delphacids, Laodelphax striatellus and Sogatella furcifera (NODA et al. 2001), as well as by the observation that specimens of Laodelphax striatellus may be horizontally infected by Wolbachia (KANG et al. 2003). To verify these hypotheses, further studies of specimens of M. pruinosa taken from different populations are needed.

\section{Acknowledgements}

We would like to express our gratitude to Dr. Jean-Francois GERMAIN (Labolatoire National de la Protection des Vegetaux, Montpellier, France) and Dr. Sebastian PILARCZYK (Silesian University, Katowice, Poland) for collection and identification of specimens. We are also grateful to Dr. Beata SZYMAŃSKA (Jagiellonian University, Department of Systematic Zoology and Zoogeography, Kraków, Poland) and Dr. Olga WoźNICKA (Jagiellonian University, Department of Cytology and Histology, Kraków, Poland) for their skilled technical assistance.

\section{References}

BAUMANN P. 2005. Biology of bacteriocyte-associated endosymbionts of plant sup-sucking insects. Annu. Rev. Microbiol. 59: 155-189.

BAUMANN P. 2006. Diversity of prokaryote-insect associations within the Sternorrhyncha (psyllids, whiteflies, aphids, mealybugs). (In: Insect Symbiosis, vol. 2. T.A. Miller, K. Bourtzis ed., Contemporary Topics in Entomology Series): 1-24.

Bourgoin T., Steffen-Campbell D., CAMPbell B. C. 1997. Molecular phylogeny of Fulgoromorpha (Insecta, Hemiptera, Archaeorrhyncha). The enigmatic Tettigometridae: evolutionary affiliations and historical biogeography. Cladistics 13: 207-224.

BUCHNER P. 1965. Endosymbiosis of Animals with Plant Microorganisms. Interscience Publishers, New York, London, Sydney.

CHENG D-J., Hou R. F. 2001. Histological observations on transovarial transmission of a yeast-like symbiote in Nila- parvata lugens Stal (Homoptera, Delphacidae). Tissue Cell 33: $273-279$

CHENG D- J., HOU R. F. 2005. Determination and distribution of a female-specific protein in the brown planthopper, Nilaparvata lugens Stal (Homoptera, Delphacidae). Tissue Cell 37: 37-45.

EBERLE M. W., MC LEAN D. L. 1982. Initiation and orientation of the symbiote migration in human body louse Pediculus humanus L. J. Insect Physiol. 28: 417-422.

FuKatsu T., ISHIKAWA H. 1996. Phylogenetic position of yeast-like symbiont of Hamiltonaphis styraci (Homoptera, Aphididae) based on 18rDNA sequence. Insect Biochem. Mol. Biol. 26: 383-388

HONGOH Y., ISHIKAWA H. 1997. Uric acid as a nitrogen resource for the brown planthopper, Nilaparvata lugens: studies with synthetic diets and aposymbiotic insects. Zool. Sci. 14: $581-586$

HONGOH Y., ISHIKAWA H. 2000. Evolutionary studies on uricases of fungal endosymbionts of aphids and planthoppers. J. Mol. Evol. 51: 265-277.

Houk E. J., GRIFFITHS G. W. 1980. Intracellular symbiotes of the Homoptera. Annu. Rev. Entomol. 25: 161-187.

ISHIKAWA H. 2003. Insect Symbiosis: An Introduction. (In: Insect Symbiosis, vol. 1. T.A. Miller, K. Bourtzis ed., Contemporary Topics in Entomology Series): 1-21

Kang L., Ma X., Cai L., LiaO S., Sun L., Zhu H., Chen X., SHEN D., ZHAO S., LI C. 2003. Superinfection of Laodelphax striatellus with Wolbachia from Drospohila simulans. Heredity 90: 71-76.

Montllor C. B., MaXmen A., Purcell A. H. 2002. Facultative bacterial endosymbionts benefit pea aphids Acyrthosiphon pisum under heat stress. Ecol. Entomol. 27: 189-195.

NODA H. 1977. Histological and histochemical observation of intracellular yeastlike symbiotes in the fat body o the smaller brown planthopper, Laodelphax striatellus (Homoptera, Delphacidae). Appl. Ent. Zool. 12: 134-141.

NODA H., SAITO T. 1979. Effects of high temperature on the development of Laodelpax striatellus (Homoptera: Delphacidae) and on its intracellular yeastlike symbiotes. Appl. Ent. Zool. 14: 64-75.

Noda H., NAKashima N., KoIZUMi M. 1995. Phylogenetic position of yeast-like symbiotes of rice planthoppers based on partial 18S rDNA sequences. Insect Biochem. Mol. Biol. 25: 639-646.

NodA H., KoIZUMI Y., ZHANG Q., DENG K. 2001. Infection density of Wolbachia and incompatibilty level in two planthopper species, Laodelpax striatellus and Sogatella furcifera. Insect Biochem. Mol. Biol. 31: 727-737.

Oliver K. M., Russel J. A., Moran N. A., Hunter M. S. 2003. Facultative bacterial symbionts in aphids confer resistance to parasitic wasps. Proc. Natl. Acad. Sci. 100: 1803-1807.

SACCHI L., GENCHI M., CleMENTI E., Bigliardi E., AVANZATTi A. M., Pajoroi M., Negri I., Marzorati M., GONElla E., Alma A., DAFFONCHIO D., BANDI C. 2008. Multiple symbiosis in the leafhopper Scaphoideus titanus (Hemiptera: Cicadellidae): Details of transovarial transmission of Cardinium sp. and yeast-like endosymbionts. Tissue Cell 40: 231-242.

SASAKI T., ISHIKAWA H. 1995. Production of essential amino acids from glutamate by mycetocyte symbiont of the pea aphid Acyrthosiphon pisum. J. Insect Physiol. 41: 41-46.

SASAKI T., KAWAMURA M., ISHIKAWA H. 1996. Nitrogen recycling in the brown planthopper, Nilaparvata lugens: involvement of yeast-like endosymbionts in uric acid metabolism. J. Insect Physiol. 42: 125-129.

Scarborough C. L., Ferrari J., Godfray H. C. J. 2005. Aphid Protected from Pathogen by Endosymbiont. Science 310: 1781 .

SzKLARZEWICZ T., MOSKAL A. 2001. Ultrastructure, distribution, and transmission of endosymbionts in the whitefly 
Aleurochiton aceris Modeer (Insecta, Hemiptera, Aleyrodinea). Protoplasma 218: 45-53.

SZKLARZEWICZ T., KĘDRA K., NiżNIK S. 2006. Ultrastructure and transovarial transmission of endosymbiotic microorganisms in Palaeococcus fuscipennis (Burmeister) (Insecta, Hemiptera, Coccinea: Monophlebidae). Folia biol. (Kraków) 54: 69-74.

SZKLARZEWICZ T., JANKOWSKA W., LUKASIEWICZ K., SZY MAŃSKA B. 2007. Structure of the ovaries and oogenesis in Cixius nervosus (Cixiidae), Javesella pellucida and Conomelus anceps (Delphacidae) (Insecta, Hemiptera, Fulgoromorpha).Arthr. Struct. Dev. 36: 199-207.

Thao M. L., Clarc M. A., Baumann L., Brennan E. B. MORAN N. A., BAUMANN P. 2000. Secondary endosymbionts of psyllids have been aquired multiple times. Curr. Microbiol. 41: 300-304
URBAN J. M., CRYAN J. R. 2007. Evolution of planthoppers (Insecta: Hemiptera: Fulgoroidea). Mol. Phylogenet. Evol. 42: 556-572.

WILKINSON T. L., ISHIKAWA H. 2001. On the functional significance of symbiotic microorganisms in the Homoptera: a comparative study of Acyrthosiphon pisum and Nilaparvata lugens. Physiol. Entomol. 26: 86-93.

Xet-Mull A. M., Quesada T., EspinOza A. M. 2004. Phylogenetic position of the yeast-like symbiotes of Tagosodes orizicolus (Homoptera: Delphacidae) based on 18S ribosomal DNA partial sequences. Rev. Biol. Trop. 52: 777-785.

ŻELAZOWSKA M., BILIŃSKI S. M. 1999. Distribution and transmission of endosymbiotic microorganisms in the oocytes of the pig louse, Haematopinus suis (L.) (Insecta: Phthiraptera). Protoplasma 209: 207-213. 